\title{
“QUEM NATO SE COMUNICA, SE ESTRUMBICA": ALGUMAS CONSIDERAÇÕES SOBRE O ROCK NACIONAL DOS ANOS 80 E A TV BRASILEIRA
}

\author{
IF YOU DON'T' TALK, YOU DON'T' WALK: SOME \\ CONSIDERATIONS ABOUT BRAZILIAN 80'S ROCK AND THE \\ BRAZILIAN TV
}

DOI: http://dx.doi.org/10.15448/2178-3748.2015.1.18181

\author{
Paulo Gustavo da Encarnação \\ Doutorando em História pela Faculdade de Ciências e Letras da UNESP/Assis \\ Bolsista FAPESP \\ E-mail: pgustavoe@yahoo.com.br
}

\begin{abstract}
RESUMO: Este artigo busca, sobretudo, traçar considerações sobre a relação de algumas bandas e cantores do rock nacional dos anos 80, com especial destaque para os primeiros anos da carreira musical profissional, com a TV brasileira. O objetivo central é tratar e refletir historicamente sobre alguns acontecimentos que ocorreram nos bastidores e nas apresentações dos roqueiros brasileiros oitentistas em programas de TV, com ênfase no programa Cassino do Chacrinha. Além disso, o artigo busca tecer algumas reflexões sobre as canções roqueiras vinculadas em novelas. Como fonte utilizamos os jornais Folha de S. Paulo e Jornal do Brasil, a revista Veja e a revista especializada em música Bizz. Portanto, a análise histórica sobre a relação de músicos roqueiros com a TV, especialmente as acusações feitas por parte dos músicos roqueiros, publicadas nas páginas dos jornais e revistas da época, de supostas práticas e cobranças de jabaculê, são questões que nos permitem refletir sobre o meio musical e suas interfaces com a mídia.
\end{abstract}

PALAVRAS-CHAVE: Rock Brasil. TV brasileira. Cassino do Chacrinha

ABSTRACT: This article above all, traces considerations about the relations of some brazilian rock ' $n$ ' roll bands and singers from the 80 's, with highlight to the first years of musical professional career, with the brazilian TV. The main goal is to reflect historically some happenings that occurred in the backstage and in the TV shows with the brazilian rockers from the 80's, with emphasis on the Cassino do Chacrinha show. Besides this, the article wishes to reflect about rock songs present in soap operas. As a source we used the newspaper Folha de S. Paulo and Jornal do Brazil, Veja magazine and the magazine in music Bizz. Therefore, the historic analysis about the relations between rockers and television, especially the accusations made by the musicians, publicized in the newspaper pages at the time, of supposed practicals of jabaculê chargings, are questions they allow us to reflect about the musical environment and its interfaces with the media.

KEY-WORDS: Rock Brazil, Brazillian television, Cassino do Chacrinha.

\section{Introdução}

Oficina do Historiador, Porto Alegre, EDIPUCRS, v. 8, n. 1, jan./jun. 2015, p. 158-176. 
Em primeiro de agosto de 1981, nos Estados Unidos, nascia a Music Television (MTV), fruto de uma parceria do conglomerado da Warner Bros. com a American Express. Enquanto um canal a cabo com 24 horas de exibição de videoclipes, dirigido a um público de 12 a 34 anos de idade, a MTV era uma nova forma de promoção e propaganda televisiva para uma banda ou canção. O primeiro videoclipe exibido pelo canal foi Video killed the radio star, dos Buggles. Nada mais irônico e sintomático que iniciar com a canção que trazia versos como: "What did you tell them?/Video killed radio star/Video killed radio star/ Pictures came and broke your heart" (O que disse a eles? / $\mathrm{O}$ vídeo matou a estrela do rádio / $\mathrm{O}$ vídeo destruiu a estrela do rádio / As imagens chegaram e partiram seu coração).

Depois de quase três anos de prejuízos, devido à falta de existência de cabos nos grandes centros urbanos americanos, a Music Television passaria a cobrar das gravadoras a transmissão dos vídeos, que até então eram veiculados gratuitamente. Inicialmente, a MTV foi catalisadora de novas bandas e músicos menos conhecidos, entretanto, em meados dos anos 80 , as gravadoras começaram a investir no padrão dos videoclipes, chegando a contratar profissionais de cinema e televisão para criação de vídeos para os músicos da mainstream (FRIEDLANDER, 2003). Em 1987, a Europa ganhava sua versão da MTV. Em sua estreia fora exibido o clipe Money for nothing, da banda Dire Straits, e, logo, o canal de exibição de videoclipes ganharia a simpatia e especialmente a audiência do público jovem.

Embora a MTV Brasil só se concretizasse em 1990, o público brasileiro, na década de 1980, não deixaria de assistir a nova onda musical-televisiva. Pois os canais de televisão do país se ocupavam com programas que exibiam videoclipes.

É interessante salientar que a segmentação da mídia estava acelerada na década, e o público jovem já era contemplado mais amplamente. No âmbito do rádio, já diferenciado entre AM e FM, ocorreria um crescimento exorbitante de emissoras de frequência modulada. Apesar de ter sido implantada no Brasil em 1955, a FM se expandiria sobremaneira devido à distribuição de concessões de rádios promovida pelo presidente José Sarney, servindo-lhe como moeda política para manter-se mais um ano à

Oficina do Historiador, Porto Alegre, EDIPUCRS, v. 8, n. 1, jan./jun. 2015, p. 158-176. 
frente da Presidência da República. Na TV, o processo de segmentação foi marcado pela criação de programas específicos, de acordo com distintas faixas etárias e culturais, com destaque para programas dirigidos ao público jovem, como Som Pop (Cultura), Geração 80 (Globo), É proibido colar (Cultura), Nova Onda (SBT), Quem sabe, sabe (Cultura). Nos jornais, foram criados cadernos especializados e, nas revistas, o processo também ganhou vulto (MIRA, 2001). O mercado de revistas teve, em 1986, um crescimento de 84 milhões de exemplares, e a expansão nos segmentos especializados das revistas deveu-se:

[...] sobretudo às estratégias de distinção social assumidas por contingentes jovens em setores ocupacionais emergentes nos serviços urbanos. Portanto, as revistas que mais cresceram em 1986 em termos de circulação (entre outras, Som Três, Motor 3, Duas Rodas, Fluir, Bizz, Ele Ela, Carícia, Mulher de Hoje, Nova, etc.) decerto se enquadram nesse padrão de consumo onde elas constituem um elemento de informação e entretenimento associado à construção de um estilo de vida, de uma ética e de uma estética, características de setores jovens em começo de sua vida profissional nos escalões mais baixos ( $\mathrm{sic}$ ) dos serviços urbanos (bancos, escritórios etc) (MICELI, 1994, p.57).

Novas editoras ou linhas editoriais voltados ao leitor jovem surgiram, incentivadas pelo sucesso de vendas alcançado por Feliz ano velho (1982), livro de autoria de Marcelo Rubens Paiva e lançado pela Editora Brasiliense. A crescente indústria do disco ganharia um impulso definitivo com o Plano Cruzado (DIAS, 2000), então arquitetado pelo ministro da Fazenda do governo José Sarney, Dílson Funaro. O Plano consistia em uma reforma monetária, sobretudo no congelamento de preços inclusive com uma severa fiscalização que integrava a população, cujos participantes recebiam a alcunha de "fiscais de Sarney" -, e na criação de um novo índice formador de preço, o Índice de Preços ao Consumidor (IPC) (MENDONÇA, 2006).

Em 1980, a porcentagem de domicílios brasileiros com TV era de 56,1\%, chegando a 73,7\% em 1990 (DIAS, 2000, p.52). Em dez anos a porcentagem de lares brasileiros que possuíam aparelho de TV aumentou em quase 20\%. Em 1986, o Brasil ocupava o décimo lugar em investimento publicitário e o sexto com gastos em propaganda na televisão, além de estar entre os maiores produtores mundiais de livros, discos e aparelhos televisores (MICELI, 1994, p.42-3).

Oficina do Historiador, Porto Alegre, EDIPUCRS, v. 8, n. 1, jan./jun. 2015, p. 158-176. 
Desse modo, programas de TV ocupados com o público jovem e com especial destaque para a exibição de videoclipes proliferavam nos anos 80 . Na grade da programação da TV brasileira havia, entre outros: Som Pop (Cultura de SP), programa criado em 1974; Clip Clip e Aventura Musical (TV Globo); FM TV (TV Manchete); B. B. Vídeo-Clip e Videorama (TV Record); Vídeo Disco e Realce Baby (TV Gazeta); Super Especial (TV Bandeirantes). Mas o programa televisivo mais disputado pelas gravadoras para vincular um videoclipe era a revista televisiva Fantástico, da Rede Globo. O programa dominical apresentava em média quatro vídeos por edição, e chegou a produzir, por alguns anos, alguns videoclipes exibidos na rede.

O fenômeno televisivo dos videoclipes não passaria despercebido pelo jornalista Miguel de Almeida do jornal Folha de S. Paulo que publicaria a seguinte matéria: "Videoclipe, um sarampo televisivo". Nesta, Almeida iniciava com tom irônico:

O último sarampo da televisão brasileira não são as entrevistas políticas, nem os debates econômicos, mas os programas de videoclipes, engenhoca que coloca em todos os aparelhos do país a voz e a imagem do próximo ídolo da juventude (FSP, 04/08/1984).

Num artigo especial para a Folha de S. Paulo, Fernando Gabeira refletia sobre o videoclipe, bem como analisava a geração de jovens e sua relação com a TV:

O criador desse imenso mercado [videoclipe] são os milhares de bebês de televisão, os jovens que começam a consumir música, depois de uma infância quase toda passada diante de um aparelho de tevê. Acostumados a um interminável espetáculo colorido, desde quando aprendem a engatinhar, estão sempre insatisfeitos, esperando que alguma coisa aconteça. $\mathrm{O}$ rock and roll para eles foi um acontecimento que marcou suas atitudes e criou um ponto de referência para o novo. Era preciso entretanto algo mais para saciar sua sede de espetáculo. Era preciso ver a música ligada a uma gama de imagens que ela podia suscitar (FSP, 17/01/1984).

A partir dos anos 80, a vinculação dos videoclipes evidencia, cada vez mais, o estrito relacionamento entre música e imagem. A geração TV, ressaltada por Gabeira, não se contentava apenas com os versos, a melodia, o solo de violão ou de guitarra, mas queria ver os efeitos de luz, os trajes, a arte cênica e sinteticamente, queria ver

Oficina do Historiador, Porto Alegre, EDIPUCRS, v. 8, n. 1, jan./jun. 2015, p. 158-176. 
espetáculo. Para tanto, nada melhor que a relação intrínseca entre imagem e música, som e movimento, rock e TV.

Como bem refletia à época, o músico e pós-graduando em Linguística, Luiz Tatit, no jornal Folha de S. Paulo, em 28 de abril de 1985, "a canção popular contemporânea cada vez mais sai para fora de si mesma e contempla o seu intérprete. [...] Uma canção que não cuide de reaviver de algum modo o seu momento interpretativo [...] certamente encontrará dificuldades para se impor no cenário musical". Para Tatit, o videoclipe era a forma mais acabada de retratar uma comunicação, pois com aquele audiovisual o músicointérprete reforça, participa, movimenta, interpreta e gesticula a música e a letra. Resultado: "O intérprete encarna a própria compatibilidade entre os elementos da canção associando-se a esta de maneira indissolúvel". Tatit exemplificava: Herbert Vianna ostentava seus óculos e fazia sucesso com a canção chamada "Óculos"; a Blitz fazia canções como histórias de quadrinhos e interpretava os personagens nos seus shows; e os Titãs, por sua vez, ensaiavam coreografias para cada canção apresentada.

Portanto, a relação entre imagem (em movimento) e música cada vez mais estreitava seus laços. Para as bandas e cantores roqueiros dos anos 80 havia, além dos clipes, duas formas de vincular uma canção ou aparecer na TV: emplacar uma canção numa telenovela e/ou se apresentar nos programas televisivos.

\section{Entre trilhas sonoras e apresentações musicais}

Uma forma de divulgar uma canção na TV era emplacá-la na trilha sonora de uma telenovela, de preferência produzida pela Rede Globo, líder de audiência no gênero. As Organizações Globo possuíam uma hegemonia avassaladora no início dos anos 80. Com sete emissoras próprias, mais seis em parceria e trinta e seis afiliadas, alcançava $98 \%$ do território brasileiro. Além disso, contava com dezoito rádios, o jornal $O$ Globo, uma produtora de vídeo e a gravadora Som Livre.

Em 1974, o violonista e compositor Guto Graça Mello fazia sua estreia como produtor de trilhas sonoras para a gravadora Sigla. A gravadora fora fundada em 1969, e

Oficina do Historiador, Porto Alegre, EDIPUCRS, v. 8, n. 1, jan./jun. 2015, p. 158-176. 
fazia parte do Sistema Globo de Comunicação, com o intuito de lançar exclusivamente discos com trilhas de telenovelas. A primeira novela que Guto Graça Mello produziu foi Cavalo de Aço, e logo elevaria a venda média de 7 mil discos para 80 mil. No início da década de 1980, as trilhas sonoras dos folhetins televisivos tinham uma receita definida por Graça Mello: uma abertura especial, duas canções de sucesso nas paradas das rádios e quatro sucessos imediatos. Em 1983, Graça Mello dizia não saber se estava "influenciando a música brasileira" com suas seleções: "O fato é que o nível da música brasileira hoje não me agrada. Está pasteurizada e não acho que tenhamos culpa nisso. Essa produção já vem pronta para as nossas mãos" (Veja, 10/08/1983). O produtor viria transformar a cantora roqueira Rita Lee, que vendia anteriormente em média 10 mil LPs, em uma cantora de sucesso nacional. O primeiro disco dessa artista, produzido por Graça Mello, Babilônia (1978), alcançou a 150 mil cópias vendidas. Já com Lança Perfume, a vendagem chegaria a 750 mil LPs. A matéria da revista Veja, de 10 de agosto de 1983, feita por Joaquim Ferreira dos Santos apontava o seguinte: “Agora, [... Graça Mello] quer transformar Fafá de Belém. Será um desafio fazer com que ela salte da média de 20.000 discos para a sua marca mínima de 100.000, marca atingida por suas últimas produções”.

Nas quarenta telenovelas globais levadas ao ar entre meados de 1982 - quando era exibida Sol de Verão e a Blitz lançava seu primeiro LP - até 1989 - ano de exibição de Top Model, folhetim eletrônico que seria concluída em 1990, chegamos aos seguintes dados sobre a participação de canções roqueiras nas trilhas sonoras: Ritchie e Lulu Santos lideram o set list das trilhas sonoras com oito canções cada; seguidos de perto por Barão Vermelho, com sete; e Os Paralamas do Sucesso, com quatro; Ultraje a Rigor, Lobão, Kid Abelha, Cazuza e Blitz, três cada; Ira!, Capital Inicial, Engenheiros do Hawaii e Titãs, uma canção cada. Nada mau quando comparado com nomes então já consagrados há muito mais tempo no cenário musical brasileiro como: Fafá de Belém, figurando com onze canções; Gal Costa, dez; Zizi Possi, Wando e Marina, nove; Caetano Veloso, Eduardo Dusek, Guilherme Arantes, Maria Bethânia, Simone, oito.

A primeira banda a ter uma canção vinculada a uma novela global foi a Blitz. A canção Você não soube me amar fez parte da trilha sonora da novela Sol de Verão, de 1982. As bandas e os cantores que tiveram suas canções executadas como tema de abertura de novelas foram: Ritchie, cuja canção Casanova fora tema da novela

Oficina do Historiador, Porto Alegre, EDIPUCRS, v. 8, n. 1, jan./jun. 2015, p. 158-176. 
Champagne, de 1983/4; Ira!, com Flores sem você, em O outro, de 1987; Ultraje a Rigor, com Pelado, em Brega \& Chique, de 1987. A canção Brasil, de autoria de Cazuza, foi tema da abertura da novela Vale Tudo, de 1988/89, entretanto a canção vinculada na telenovela contava com a interpretação da cantora Gal Costa.

Jamari França "alertava" os roqueiros sobre a inclusão das canções em coletâneas lançadas pela Som Livre, muitas, inclusive, associadas a novelas: “(...) quem acaba faturando o grosso é a vampiragem da Som Livre que junta todas as músicas de sucesso num único LP, vende horrores com a ajuda do veículo número um de comunicação e o LP das bandas dança em vendagens" (Jornal do Brasil, 19/04/1985). Em matéria anterior, o crítico lembrava aos roqueiros que eles tinham direito contratual de $7 \%$ sobre um disco, mas:

(...) só tem direito a metade disso, $3.5 \%$, quando o fonograma seu é cedido para os discos globais, incluindo os carros-chefe que são as trilhas sonoras de novelas, onde os diretores armam cenas especialmente para vender as mais escolhidas. As coletâneas têm o mal adicional de desviar o público do trabalho das bandas, fazendo com que a maioria só conheça uma música ou outra (JB, 01/04/1985).

Se o direito autoral sobre determinada canção selecionada para uma trilha sonora global rendia aos compositores um valor menor que o estipulado para um LP comum, talvez essa prerrogativa não fosse tão importante quanto vincular uma música para as novelas que eram assistidas por milhões de telespectadores, inclusive estrangeiros, uma vez que as telenovelas brasileiras eram exportadas para diversos países, o que poderia proporcionar uma forma de propaganda das canções roqueiras brasileiras em outros continentes.

Aparecer na telinha era outra forma de propaganda e visibilidade para as bandas e cantores do rock nacional dos anos 1980 apresentarem suas canções, embora o que predominasse nos programas televisivos eram as apresentações com playback, fato que inclusive gerou reclamações de músicos, produtores e empresários (Jornal do Brasil, 27/12/1985). Uma das formas de tornar o rock nacional dos anos 80 conhecido nacionalmente era por meio da TV, e para tanto, muitas vezes os músicos tinham que se submeter a determinadas situações.

Oficina do Historiador, Porto Alegre, EDIPUCRS, v. 8, n. 1, jan./jun. 2015, p. 158-176. 
Antes do sucesso obtido com duas apresentações na Cidade do Rock, Os Paralamas do Sucesso estiveram no programa infantil do palhaço Bozo, no SBT. Para divulgar o trabalho, via playback, os músicos tiveram que participar de gincanas, como encher balões de festa, representando competidores, os quais eram telespectadores mirins que participavam da competição por telefone.

Os Titãs foram frequentadores assíduos de uma gama variada de programas televisivos. Fato que assumiam sem preconceitos e pudores. Arnaldo Antunes, um dos vocalistas e compositores da banda, até sairia em defesa da televisão e de seu avanço, inclusive alfinetou o meio universitário:

A crítica da televisão que monstrifica o seu aspecto massificante exclui um elemento fundamental do processo, que é o telespectador. Se não exclui, menospreza sua capacidade de manipular o aparelho. $\mathrm{O}$ cuidado em não se promiscuir com os raios catódico-emburrecedores é gerado pela preguiça de cavar uma maneira própria de se relacionar com o objeto. Mais cômodo é afastar qualquer possibilidade de contaminação. Mais antisséptico. As pessoas se preservam do risco de envolvimento com a mediocridade televisada para a repetirem mediocridade universitária. [...] Eu quero é mais: tevês de bolso, tevês descartáveis, telas circulares, novas possibilidades de alteração da imagem, maior número de emissoras, programação constante sem interrupção de madrugada (...) (FSP, 28/10/1985).

Em 1984, a Rede Globo organizava mais uma trilha musical para comemorar as festas de final de ano. Dentre as dez canções selecionadas, os Titãs tiveram a canção Sonífera Ilha incluída e executada no horário nobre da TV global, inclusive com chamada na novela das sete $(60 \%$ de audiência na época). Sobre o fato, os músicos refletiram na época: "Não era opção nossa ficar com o circuito menor, apenas o maior não tinha pintado. [...] Nossa intenção sempre foi atuar na massa". Os oito titãs não escondiam a intenção de querer conquistar o maior público possível, de estar constantemente aparecendo na telinha mágica e participar do jogo midiático. Tanto que os músicos não cobraram nada para executar a canção na TV, preferiam enxergar a situação como propaganda da música e intrinsecamente da banda. "Não estamos em condições de recusar essas aparições por falta de cachê, como a Blitz e o Barão Vermelho fizeram" (Folha de S. Paulo, 08/12/1984), ressaltavam os músicos. Ter uma canção executada no

Oficina do Historiador, Porto Alegre, EDIPUCRS, v. 8, n. 1, jan./jun. 2015, p. 158-176. 
horário nobre de uma emissora de televisão de maior audiência no país, talvez fosse um meio que a banda encarou a falta de cachê, pois era uma forma de divulgação. A Blitz e o Barão Vermelho não aceitaram, talvez, porque na época faziam sucesso tanto na TV quanto nas rádios. A Blitz já estava com seu terceiro disco emplacado e com várias canções tocando nas rádios. O Barão Vermelho também já tinha três álbuns lançados, embora com menos êxito nas vendas, mas naquele exato ano, a canção Bete Balanço era uma das mais executas no país e trazia certo sucesso de vendas e público para a banda.

Mas não foram somente os Titãs que estavam aparecendo na TV. A maioria das bandas e cantores se apresentava em programas como o Perdidos na Noite, Hebe Camargo e principalmente Cassino do Chacrinha. Muitos músicos na época ressaltaram que era preciso saber utilizar o meio midiático e não ser apenas absorvida por tal. Como os Titãs, que ao se apresentarem em programas de TV com cabelos, roupas e coreografias exóticas viam nesse aspecto uma forma de "agir", ou como explicou Tony Bellotto: "É um terceiro jeito de agir que fica entre o dizer não a essa estrutura e o sim total. É um jeito de entrar lá dentro e alucinar com aquilo" (Folha de S. Paulo, 17/08/1984).

Opinião próxima era apresentada pelo Ira!. Embora a banda aparecesse menos na TV em relação aos Titãs, seus integrantes justificavam o pouco contato com os meios de comunicação nos seguintes termos: "Nós queremos acabar com esse estigma de que somos contra os meios de comunicação. Nós só queremos usá-los do nosso jeito, para continuar com a consciência tranquila" (Bizz, abril de 1989). A ideia do titã Bellotto, de que o visual e as danças exóticas eram uma forma da banda "alucinar" a estrutura da TV soava até de forma ingênua. Pois, a TV vez por outra capta exatamente essas características não familiares, transformando-a em similar e produto de mais uma atração.

Porém, nem sempre este expediente é certeiro. O caso dos baianos da Camisa de Vênus é um bom exemplo do insucesso daquele esquema televisivo. Após gravar um LP pela Som Livre, os integrantes da Camisa de Vênus tiveram um desentendimento com a gravadora, que insistira para que o conjunto trocasse de nome, pois se acreditava que o mesmo dificultaria a entrada do grupo na mídia. Os músicos não concordaram com a proposta e quebraram o contrato, chegando a passar por dificuldades financeiras na cidade de São Paulo. Mas como a vida também é feita de contradições e ironias, os baianos viriam a assinar contrato com a RGE, paradoxalmente ou não, a gravadora

Oficina do Historiador, Porto Alegre, EDIPUCRS, v. 8, n. 1, jan./jun. 2015, p. 158-176. 
pertencia a Som Livre. Conforme as palavras de Marcelo Nova, vocalista da banda: “Quando Joana D’Arc virou hit de rádio e invadiu a tal da mídia e a banda vendeu 100 mil LPs, fomos convidados para fazer Chacrinha e com o mesmo nome. Porque aí a falsa moral caiu por terra. O que era indecente passou a ser sarcástico. Sabe, aquela mentalidade: Esse nome é bom, é sarcástico, vende 100 mil cópias e a gente vai ganhar dinheiro" (Bizz, outubro de 1986).

Ao provarem cada vez mais da TV, ou talvez por já ostentarem certo capital cultural no meio musical, que inclusive ia lhes garantindo certas escolhas televisivas, os jovens roqueiros percebiam o poder da estrutura do meio. Como o caso dos Titãs: "Fizemos dezoito programas do Barros de Alencar, cantando Sonífera Ilha com coreografia e roupas coloridas, achando que seria uma ruptura, mostraria que dava para fazer algo lá dentro. Só que a TV te engole” (Bizz, novembro de 1989).

O Ultraje a Rigor, em 1985, se tornaria a banda de maior sucesso entre público e crítica com o LP Nós vamos invadir sua praia. No final daquele ano, a banda foi convidada para participar do programa Especial do Roberto Carlos, na Rede Globo. Estava programado que os paulistas iriam cantar Quero que vá tudo pro inferno, do excantor da Jovem Guarda; e a canção Ciúmes, da banda, seria cantada por ambos. Segundo Jamari França em sua coluna no Jornal do Brasil, em 27 de dezembro de 1985: "Essa última teve que ser repetida depois de pronta porque Roberto Carlos achou que o Ultraje foi muito exuberante no palco, e o rei se sentiu abafado e mandou repetir, segurando a animação dos meninos. No mais, a velha tática dele para se manter sempre na frente: aparecer com quem está em número um”. Mas o programa que mais atraiu músicos na década de 1980 foi o Cassino do Chacrinha.

\section{Os roqueiros brasileiros dos anos 80 no Cassino do Chacrinha.}

O programa Cassino do Chacrinha era apresentado por Abelardo Barbosa de Medeiros, o Chacrinha, e entrava no ar nas tardes de sábado na TV Globo. O Cassino existiu de 1982 a 1988, ano que o "Velho Guerreiro" faleceu. Pelo programa global, que

Oficina do Historiador, Porto Alegre, EDIPUCRS, v. 8, n. 1, jan./jun. 2015, p. 158-176. 
era líder de audiência nas tardes de sábado, passaram desde Chico Buarque de Holanda ao grupo Dominó.

A Blitz com suas performances teatrais foi uma frequentadora assídua do programa, como conta Evandro Mesquita: “A Blitz era a cara do Chacrinha. Ele amou desde a primeira vez, então éramos marcados todo sábado. [...] Era realmente o programa mais gostoso de se fazer" (Apud BRYAN, 2004, p.196).

Mas nem todos os roqueiros tiveram uma relação amistosa e harmônica com o apresentador. Chacrinha e sua produção sempre implicavam com as roupas de algumas bandas como a Legião Urbana, a Plebe Rude e Engenheiros do Hawaii. Em junho de 1985, Jamari França, abria espaço em seu artigo para as reclamações de Renato Russo sobre uma apresentação no programa do Chacrinha. Segundo o crítico, o "Velho Guerreiro" tinha feito um programa só com bandas de rock, e aproveitou para fazer críticas à gravação de Será, da Legião Urbana. Renato se defendeu dizendo que a censura ocorreu porque eles não usaram a roupa que a produção exigia: "Renato se queixou da total falta de direção, eles foram empurrados para a cena, não sabiam onde ficar, foram apresentados como metaleiros de Rondônia e se o microfone não estivesse fechado ia dar um tic tic na plateia, porque Renato mandou logo que metaleiro de Rondônia é a ...(impublicável)" (Jornal do Brasil, 28/06/1985).

A Legião Urbana faria outra apresentação no final do ano de 1986, e além de trocar as calças rasgadas e se vestir com roupas "new wave" da marca Company tiveram que usar touca de Papai Noel. A Plebe Rude também experimentaria as implicações da produção do programa com suas vestimentas rasgadas. Os integrantes dos Engenheiros do Hawaii também tiveram problema de vestuário, mas ao invés de calças rasgadas, apareceram todos de branco, para desespero da produção que "sugeria" sempre roupas coloridas. Humberto Gessinger reclamou dessa situação em 1987: “É necessário que as pessoas ouçam isso. Estes caras são fascistas! Imagina: um cara chega, olha tua roupa de cima a baixo, e - eles não falam direto contigo - chama o divulgador da RCA pra dizer que lá embaixo tem a camisaria da Globo, com uns blazerzinhos pra gente botar, senão não vai ao ar (pausa). Tava o maior calor, eu não ia pôr blazer” (Bizz, abril de 1987).

Aparecer em um programa de alto índice de audiência como o Cassino do Chacrinha, que era visto por 30 milhões de espectadores em média (Folha de S. Paulo,

Oficina do Historiador, Porto Alegre, EDIPUCRS, v. 8, n. 1, jan./jun. 2015, p. 158-176. 
23/01/1987), era uma forma de divulgar mais facilmente o trabalho de um músico para todo o país. Mas os inconvenientes não foram apenas os vestuários, os trajes foram apenas um minúsculo atrito. A reclamação-denúncia do vocalista dos Engenheiros do Hawaii, citada anteriormente, foi colírio perto das denúncias de roqueiros sobre um "esquema" que girava em torno do Cassino do Chacrinha: o jabaculêt, ou como é popularmente conhecido, jabá.

Em 23 de janeiro de 1987, o jornal Folha de S. Paulo publicou a reportagem intitulada: "Como se fabrica o sucesso". Nela, roqueiros denunciavam que para participarem do programa do "Velho Guerreiro" era necessário que fizessem alguns shows de graça, todos organizados e capitalizados pelo produtor Leleco Barbosa - filho de Chacrinha - e realizados em clubes da Baixada Fluminense. Segundo Paulo Ricardo, vocalista e baixista do RPM, entrevistado pelo jornal, era uma troca normal. "Você faz playback de graça, o dinheiro fica com o produtor do Chacrinha e é divulgado na TV".

O Capital Inicial fez, segundo os músicos da banda, doze shows pelo subúrbio para pagar as quatro apresentações no programa. Felipe Lemos, baterista da banda de Brasília, ainda ressaltou: "Sabemos que a gravadora Polygram pagou para que pudéssemos nos apresentar novamente". Armando Pittigliani, diretor de marketing da Polygram na época, esquivava-se das acusações e comentou que "o playback é uma forma de se promover, mas nunca pagamos para grupo nenhum" (Folha de S. Paulo, 23/01/1987). Leleco Barbosa se defendia na mesma reportagem: "Isso não existe, não é uma troca de nada".

Com as denúncias de Paulo Ricardo e Felipe Lemos, o vice-presidente à época da Rede Globo, José Bonifácio de Oliveira Sobrinho, convocaria a equipe do programa. Segundo Sobrinho, "todos eles repudiaram com veemência as acusações. Estamos certos, portanto, de que se algum caso desse tipo realmente ocorreu foi por iniciativa de elementos estranhos à produção, que envolveram levianamente os seus responsáveis na extorsão". E, por fim, decidiram enviar cartas às gravadoras convocando os respectivos presidentes das empresas para discutir o problema. A carta concluía: “A Rede Globo não

1Jabaculê segundo o vocabulário de música pop "designa a oferta de favores financeiros, sexuais ou de outra natureza em troca de promoção e divulgação" (SHUKER, 1999, p.180).

Oficina do Historiador, Porto Alegre, EDIPUCRS, v. 8, n. 1, jan./jun. 2015, p. 158-176. 
admite em hipótese alguma, tal procedimento. Por isso solicitamos que qualquer tentativa de cobrança que possa a vir ocorrer seja imediatamente comunicada à direção da empresa para que possamos acionar as providencias legais cabíveis" (Folha de S. Paulo, 25/01/1987).

Embora a Globo se justificasse, a Folha de S. Paulo continuaria com a série de reportagem sempre intitulada "A cultura da armação". Mario César Carvalho, repórter encarregado das reportagens, comentaria o caso do sambista Osvaldo Nunes com Chacrinha. Promovido pela Rádio Nacional do Rio de Janeiro, o debate batizado de "O jabá está solto, salve-se quem puder", Osvaldo Nunes e Chacrinha "quase foram às vias de fato". O sambista acusou no ar o apresentador de Chacrinha de cobrar em dinheiro as aparições no programa de TV (Folha de S. Paulo, 29/01/ 1987).

Na mesma matéria, o cantor Ritchie, que já havia se apresentado em mais de vinte programas do "Velho Guerreiro", esquentava a discussão. O cantor que tinha emplacado as canções Menina veneno, Casanova e Pelo telefone, sucessos radiofônicos em 1983 e 1984, comentava que "não ligava em fazer playback de graça para o Velho Guerreiro em clubes da Baixada Fluminense", uma das formas de se pagar a apresentação no Cassino do Chacrinha. Entretanto, o cantor estrilou com Chacrinha quando este marcou um show para ele sem consultá-lo e sem pagar cachê. Devido à suas queixas, Ritchie declarou que como punição nunca mais apareceu no programa. Com isso, aproveitou para disparar que o "jabá tem que acabar. Se as pessoas querem ganhar dinheiro, têm que trabalhar" (Folha de S. Paulo, 29/01/ 1987).

Aproveitando para fazer propaganda, do então, lançamento da segunda edição do "Manual de Redação da Folha", o jornal explicava semanticamente aos leitores o que designava jabaculê: "O presente recebido pelo jornalista em sua condição de profissional. A Folha considera que a atitude diante de jabaculês é decisão pessoal de cada jornalista. Recomenda-se recusa, exceto quando forem desprovidos de valor material ou quando forem de utilidade para ao trabalho jornalístico". Dizia o jornal: "A Folha aceita convites de viagem, mas a fonte pagadora das despesas sempre é citada na reportagem" (Folha de S. Paulo, 23/01/1987).

O Capital Inicial teve sérios problemas com a gravadora CBS devido à sua recusa em participar dos programas televisivos de Hebe Camargo e Flávio Cavalcanti. Após gravar

Oficina do Historiador, Porto Alegre, EDIPUCRS, v. 8, n. 1, jan./jun. 2015, p. 158-176. 
um compacto pela gravadora e com a promessa de lançar um LP, o Capital Inicial viu-se às voltas com o pouco empenho da gravadora em divulgar seu disco em rádio e mesmo em programas de TV. Para participar do programa televisivo do Chacrinha tinha que participar do "esquema" do jabaculê, como denunciaram os roqueiros. Entretanto, tinha também a divulgação, inclusive de canções de pouco sucesso radiofônico, por meio dos paus-de-sebo, isto é, uma compilação de bandas e cantores roqueiros era reunida num LP, sendo que cada um dos participantes apresentava na maioria das vezes uma única canção. Como a coletânea de canções intitulada Cassino do Chacrinha, com as respectivas músicas: Tudo pode mudar, do Metrô; Loiras Geladas, do RPM; Eh! Oh!, do Dr. Silvana e Cia; Popstar, do João Penca \& Seus Miquinhos Amestrados; Olhos Vermelhos, de Guilherme Arantes; Eu queria ter uma bomba, do Barão Vermelho; Amante Profissional, do Herva Doce; Alice (não me escreva aquela carta de amor), do Kid Abelha; Não me iluda, do Cinema à Dois; Humanos, Tókio; Novamente aconteceu, da Gang 90 \& As Absurdetes; Só, de Leo Jaime (CASSINO do Chacrinha. Rio de Janeiro: Som Livre, 1985. Long-Play).

Anos mais tarde os integrantes da banda Ira! comentaram sobre o posicionamento do conjunto frente às aparições na TV e também ao jabaculê em geral. "Poderíamos ser muito mais populares se soubéssemos conviver melhor com o jabaculê. Existem programas de TV, por exemplo, que não poderíamos ter feito, sem comprometer a nossa imagem. O problema é que nós raciocinávamos como uma gangue. O resultado disso é que até hoje temos dificuldades para ir tocar no Norte e ainda não conseguimos sair do Brasil" (Bizz, maio de 1990).

A mesma sensação por não ter sido veiculado em programas de TV era expressada pela Plebe Rude: "Não tínhamos feito Chacrinha porque achávamos que "A ida" não era legal para tocar lá. Mas, tudo bem. Não é nem questão de estar arrependido. Teria sido legal se o Brasil inteiro tivesse conhecido e, bem, acabaram conhecendo, porque essa música foi bem. No interior só toca sucessos garantidos da capital, então as pessoas não conheciam nem o disco anterior", declarou Phillippe Seabra à revista Bizz de julho de 1988.

Oficina do Historiador, Porto Alegre, EDIPUCRS, v. 8, n. 1, jan./jun. 2015, p. 158-176. 


\section{Considerações finais}

Por meio deste artigo buscamos tratar e refletir historicamente sobre a relação de algumas bandas e cantores do rock nacional dos anos 80 com a TV brasileira. Buscamos enfatizar alguns acontecimentos que ocorreram nos bastidores e nas apresentações dos roqueiros brasileiros no programa Cassino do Chacrinha. Especialmente as acusações feitas por parte dos músicos, publicadas nas páginas dos jornais da época, de supostas práticas e cobranças de jabaculê. Além disso, buscamos tecer reflexões sobre as canções do rock nacional dos anos 80 vinculadas em novelas e o funcionamento e as estratégias de vendas por parte da Som Livre.

Como podemos perceber a relação dos músicos com TV não foi harmônica. Para divulgar o trabalho muitas vezes foram "obrigados" a entrar no jogo; foi necessário participarem de programas televisivos infantis; fazer shows de playback para apresentarem no Cassino do Chacrinha. Como disse Renato Russo anos depois: "No começo a gente só apareceu no Chacrinha uma vez. E, de repente, o homem ainda não tinha gostado, porque eu apareci todo rasgado. 'Por que não vai passar no Chacrinha?' [...] a gente tem que aparecer nas paradas: isso eu faço! Então tomamos um banho de loja na Company"” (FRÓES, 1997, p.14-5). A fala de Renato Russo sintetiza a visão de uma parcela de roqueiros dos anos 80. Ou seja, a importância de aparecer na TV, especialmente no início da carreira e da entrada no campo musical e midiático. Mesmo que para isso tivesse que se sujeitarem às mudanças de vestimentas e/ou de fazerem shows de playback pelos subúrbios cariocas como moeda de troca para pagar as apresentações no programa do "Velho Guerreiro".

Por meio do conceito de capital cultural cunhado por Pierre Bourdieu (1979), ou seja, o conjunto de qualificações intelectuais produzidas pelo sistema escolar ou transmitidas pela família, foi-nos possível perceber que alguns músicos roqueiros foram, ao adentrarem no meio televisivo, aprendendo a jogar melhor as regras do jogo. Assim, os roqueiros foram assimilando e compreendendo o funcionamento do meio televisivo.

Oficina do Historiador, Porto Alegre, EDIPUCRS, v. 8, n. 1, jan./jun. 2015, p. 158-176. 
Garantindo-lhes, portanto, certas escolhas televisivas, uma vez que já tinham percepção do poder da estrutura do meio televisivo.

Assim, acreditamos que a análise histórica sobre a relação de músicos do rock nacional dos anos com a TV permitiu trazer, além de dados históricos sobre os bastidores de alguns programas televisivos ocupados com apresentações musicais e sobre canções roqueiras vinculadas em novelas, elementos de compreensão sobre o próprio meio musical, uma vez que as mídias, no caso a TV, atravessa e perpassa constantemente o universo musical.

\section{REFERÊNCIAS BIBLIOGRÁFICAS}

ABRAMO, Helena Wendel. Cenas juvenis: punks e darks no espetáculo urbano. São Paulo: Página Aberta, 1994.

AGUIAR, Joaquim Alves de. Panorama da música popular brasileira: da Bossa Nova ao rock dos anos 80 In: SOSNOWSKI, S; SHWARTZ, J. (Orgs.). Brasil: O trânsito da memória. São Paulo: Edusp, 1994.

ALVES JUNIOR, Carlos; MAIA, Roberto. Rock Brasil, o livro: um giro pelos últimos 20 anos do rock verde e amarelo. São Paulo: Esfera, 2003.

ALEXANDRE, Ricardo. Dias de luta: o rock e o Brasil dos anos de 1980. São Paulo: DBA Artes Gráficas, 2002.

ALZER, Luiz André; ALZER, Luiz A. B. F.; CLAUDINO, Mariana Costa. Almanaque anos 80. Rio de Janeiro: Ediouro, 2004.

BOURDIEU, Pierre. As regras da arte. São Paulo: Companhia das Letras, 1996.

. O poder simbólico. Lisboa: Difel, 1989.

. Questões de sociologia. Rio de Janeiro: Marco Zero, 1983.

. Sobre a televisão. Rio de Janeiro: Jorge Zahar, 1997.

. Os três estados do capital cultural. In: NOGUEIRA, Maria Alice; CATANI,

Afrânio (Org.). Escritos de educação. Petrópolis: Vozes, 1979. p. 73-79 (3. ed., 2001).

BRYAN, Guilherme. Quem tem um sonho não dança: cultura jovem brasileira nos anos 80. Rio de Janeiro: Record, 2004.

Oficina do Historiador, Porto Alegre, EDIPUCRS, v. 8, n. 1, jan./jun. 2015, p. 158-176. 
BUSETTO, Áureo. A mídia brasileira como objeto da história política: perspectivas teóricas e fontes. In: SEBRIAN, R. N. N.; PIRES, A. J.; GANDRA, Edgar Ávila; NETTO, F. F. (Orgs.) Dimensões da política na historiografia. Campinas: Pontes Editores, 2008.

Sintonia com o contemporâneo - a TV como objeto e fonte da História. In: Beired, José Luís B., Barbosa, Carlos Alberto S.. (Org.). Política e identidade cultural na América Latina. 1a.ed.São Paulo: Cultura Acadêmica, 2010, v. , p. 153-175.

- Imagens em alta indefinição - produção televisiva brasileira nos estudos históricos. In: Gawryszewski, Alberto. (Org.). Imagem em debate. 1a.ed.Londrina: EDUEL, 2011, v. , p. 161-177.

CARVAlHO, J. M. "O Brasil, de Noel a Gabriel”. In: CAVALCANTE, Berenice; STARLING, Helena; EINSENBERG, José (orgs). Decantando a República: inventário histórico e político da canção popular moderna brasileira. v.3: A cidade não mora mais em mim. Rio de Janeiro: Nova Fronteira, São Paulo: Fundação Perseu Abramo, 2004.

CHACON, Paulo. O que é rock. 5. ed. São Paulo: Brasiliense, 1995. (Coleção Primeiros Passos).

DAPIEVE, Arthur. Brock: o rock brasileiro dos anos 80. 3. ed. Rio de Janeiro: 34, 2000.

Ed., 2004.

Guia de rock em CD: uma discoteca básica. 2. ed. Rio de Janeiro: Jorge Zahar

DIAS, Marcia Tosta. Os donos da voz: indústria fonográfica brasileira e mundialização da cultura. São Paulo: Boitempo/Fapesp, 2000.

ENCARNAÇÃO, Paulo Gustavo da. "Brasil mostra a tua cara": rock nacional, mídia e a redemocratização política (1982-1989). Dissertação de Mestrado em História apresentada na Faculdade de Ciências e Letras de Assis, Universidade Estadual Paulista, Assis, 2009, 192 p.

. Rock in Rio: um festival (im)pertinente à música brasileira e à redemocratização nacional.. Patrimônio e Memória (UNESP), v. 07, p. 348-368, 2011.

FRIEDLANDER, Paul. Rock and roll: uma história social. 2. ed. Trad. A. Costa. Rio de Janeiro: Record, 2003.

FRÓES, Marcelo; PETRILlO, Marcos. Entrevistas: Internacional Magazine [Compilação]. Rio de Janeiro: Gryphus, 1997.

HOBSBAWM, Erick. Era dos extremos: o breve século XX, 1914-1991. Trad. Marcos Santarrita. 2. ed. 38. reimpressão. São Paulo: Companhia das Letras, 1995.

JARDIM, Eduardo. "Que país é este". In: CAVALCANTE, Berenice; STARLING, Helena; EINSENBERG, José (orgs). Decantando a República: inventário histórico e político da canção popular moderna brasileira. v.1: Outras conversas sobre os jeitos da canção. Rio de Janeiro: Nova Fronteira, São Paulo: Fundação Perseu Abramo, 2004.

MENDONÇA, Sonia Regina de; FONTES, Virginia Maria. História do Brasil recente: 1964 - 1992. 5.ed. São Paulo: Ática, 2006.

Oficina do Historiador, Porto Alegre, EDIPUCRS, v. 8, n. 1, jan./jun. 2015, p. 158-176. 
MICELI, Sérgio. O papel político dos meios de comunicação de massa. In: SOSNOWSKI, Saul; SCHWARTZ, Jorge (Orgs.). Brasil: O trânsito da memória. São Paulo: Edusp, 1994.

MIRA, Maria Celeste. O leitor e a banca de revistas: a segmentação da cultura do século XX.São Paulo: Olho d' Água/Fapesp, 2001.

MUGGIATI, Roberto. Rock, o grito e o mito: a música pop como forma de comunicação e contracultura. Petrópolis, Vozes, 1981

NAPOLITANO, Marcos. História \& música: história cultural da música popular. Belo Horizonte: Autêntica, 2002.

. "Seguindo a canção": engajamento político e indústria cultural na MPB (19591969). São Paulo: AnnaBlume, 2001.

RIDENTI, Marcelo. Em busca do povo brasileiro: artistas da revolução, do CPC à era da TV. Rio de Janeiro: Record, 2000.

. Cultura e política: os anos 1960-1970 e sua herança. In: FERREIRA, Jorge; DELGADO, Lucilia de A. N. (orgs.) O Brasil Republicano: o tempo da ditadura e os movimentos sociais no fim do século XX. v.3. Rio de Janeiro: Civilização Brasileira, 2003.

RODRIGUES, Marly. A década de 80 Brasil: quando a multidão voltou às praças. 3. ed. São Paulo: Ática, 1999. (Série Princípios).

SILVA, Francisco Carlos Teixeira da. Crise da ditadura militar e o processo de abertura política no Brasil, 1974-1985. In: FEREIRA, Jorge; DELGADO, Lucilia de A.N. (orgs.) O Brasil republicano. O tempo da ditadura: regime militar e movimentos sociais em fins do século XX. v.4. Rio de Janeiro: Civilização Brasileira, 2003.

SHUKER, Roy. Vocabulário de música pop. Trad. Carlos Szlak. São Paulo: Hedra, 1999. TINHORÃO, J.R. História social da música popular brasileira. São Paulo: 34, 1998.

VIANNA, Hermano. O mistério do samba. 4.ed. Rio de Janeiro: Jorge Zahar: UFRJ, 2002.

\section{FONTES DOCUMENTAIS}

ALMEIDA, Miguel de. Videoclip, um sarampo televisivo. Folha de S. Paulo. São Paulo, 04/08/1984. Ilustrada, p.39.

ANTUNES, Arnaldo. A realidade também emburrece. Folha de S. Paulo. São Paulo, 28/10/1984. Ilustrada, p.25.

BIZZ 20 anos. A Coleção Completa da maior revista de música do Brasil. $1^{\circ}$ edição. 7 CDs. São Paulo: Editora Abril, 2005.

Oficina do Historiador, Porto Alegre, EDIPUCRS, v. 8, n. 1, jan./jun. 2015, p. 158-176. 
CARVALHO, Mauro Cesar. Como se fabrica um sucesso. Folha de S. Paulo. São Paulo, 23/01/1987. Ilustrada, p.29.

. Globo se reúne e discute "Cassino do Chacrinha". Folha de S. Paulo. São Paulo, 25/01/1987. Ilustrada, p.60.

. Jabá revigorou, diz sambista. Folha de S. Paulo. São Paulo, 29/01/1987. Ilustrada, p.39.

CASSINO do Chacrinha. Rio de Janeiro: Som Livre, 1985. Long-Play.

FRANÇA, Jamari. Barão, Analfas, Biquíni Cavadão, Gil. Jornal do Brasil. Rio de Janeiro, 01/04/1985, Caderno B, p.08.

. Blues Boy com Mixto Quente. Jornal do Brasil. Rio de Janeiro, 27/12/1985, Caderno B, p.10.

B, p.09.

. Vai bem esse tal de rock. Jornal do Brasil. Rio de Janeiro, 26/06/1985, Caderno

FOLHA DE S. PAULO. Os Titãs, a fúria e energia, também agora na Globo. Folha de S. Paulo. São Paulo, 08/12/1984. Ilustrada, p.62.

GABEIRA, Fernando. Vídeo rock, uma nova maneira de dizer. Folha de S. Paulo. São Paulo, 17/01/1984. Ilustrada, p.31.

SANTOS, Joaquim Ferreira dos. O mago das trilhas. Veja. São Paulo. N. 779, p.128-9. Ago./1983.

SINGER, André. Os Titãs, oito fantasmas na máquina do som. Folha de S. Paulo. São Paulo, 17/08/1984. Ilustrada, p.42.

TATIT, Luiz. Os pára-lamas paradiscursivos da canção. Folha de S. Paulo. São Paulo, 28/04/1984. Folhetim, p.10.

ARTIGO ENVIADO EM: 31/07/2014

ACEITO PARA PUBLICAÇÃO EM: 03/04/2015

Oficina do Historiador, Porto Alegre, EDIPUCRS, v. 8, n. 1, jan./jun. 2015, p. 158-176. 